\title{
The Historical and Ecological Analysis of Middle Volga Industrial Development in Russia in the Second Half of the XXth Century
}

\author{
Aidar M. Kalimullin ${ }^{1}$ \\ ${ }^{1}$ Kazan (Volga region) Federal University, Kazan, Russia \\ Correspondence: Aidar M. Kalimullin, Kazan (Volga region) Federal University, Kremlyovskaya Street 18, \\ Kazan, 420008, Russia.
}

Received: December 29, 2014

Accepted: January 22, 2015 Online Published: February 11, 2015

doi:10.5539/res.v7n4p172

URL: http://dx.doi.org/10.5539/res.v7n4p172

\begin{abstract}
The relevance of this article is substantiated by the fact that ecology along with economy and international relations is among three basic problems of modern Russian society development. In this context the historical and ecological analysis of the country's industrial growth allows to trace the nature and reaction to the ecological degradation that determined the environment critical state at the present stage. The article provides the results of the historical and ecological analysis of Middle Volga area industrial development in the second half of the XX century in Russia. They allowed to designate the prospective guidelines of environment state optimization in the researched region. The materials of this article may be used for the purpose of effective economic, legal, technological, moral and organizational methods application to impact the forming economic system, its maximum ecologization to balance the development of diverse processes: economic development of the country and creation of the environment favorable for person's life and health.
\end{abstract}

Keywords: ecological history, historical and ecological analysis, industrial development, Middle Volga area in Russia

\section{Introduction}

The global character of the ecological crisis posing a serious threat for further development of the humanity put forward the necessity to study sources and evolution of contradictions in the "person nature" system as an actual scientific task (Tupikov, 1993; Kalimullin \& Vinogradov, 2015; Palekhova, 1991). The significance of such statement is explained by those cardinal changes in the development of modern civilization when there was clearly revealed the disproportionate growth of world's population, increase in energy consumption, resources, food caused large-scale environmental pollution that in turn negatively reflected on living conditions of people - the purity of soil, water, air, food security (Sokolov, 1995; Sokolov, 1994; Kalimullin, 2015).

The importance of the researched issue is substantiated by the fact that ecology along with economy and international relations is among three basic problems of modern Russian society development. Inclusion of the Russian Federation in the world's civilization process guided by the model of a sustainable development determines the necessity to choose the strategy of social-economic growth combining reasonable progress with minimization of nature damage.

Due to the problem unity, deep internal interrelation of all its components and phenomena, the representatives of various areas of scientific knowledge should take part in its solution; the historical science should play the key role. Its major task in environmental problems research is, first of all, the search of new paradigms of civilization development on the basis of prior experience analysis of person's interaction with the nature that, undoubtedly, enriches humankind's ideas of possible ecologic-economic contradictions the consequences of which may be evident in modern reality as well.

Theoretical and methodological provisions and conclusions singled out in historical and ecological researches allow to determine major ways of further social-economic development facilitating thereby the stability of an ecologic-economic situation in the country on the whole and in specific regions in particular (Pushkarenko, 2000; Bragina, Ignatovich, \& Saryan, 1999; Matveyeva, 1996). Proceeding from this, the historical research of environmental problems caused by industrial development in Middle Volga area in the second half of the XX century which includes methodological and theoretical bases for historical and ecological perspective formation, 
the historiographic analysis of the issue, the essence of society productive forces and environment interaction, regional features of contradictions in the system "person-industry-nature", the content, implementation and results of environmental policy in the 1950-1990s allowed the author to formulate the following conclusions.

\section{Methodological Framework}

Historians' consistently increasing scientific interest in various aspects of nature protection issues in the end of the XXth century resulted in the development of a new guideline in the historical science-ecological history. Ecological history contributing to the development of humankind's world outlook provides the clue to the understanding of universal, global human civilization and local civilizations as their attitude to the around world has much in common. It is historical science that may quite fully answer these questions since the knowledge of the past is a basic condition for understanding peculiarities of a modern ecological situation. Any information on ecological crises in the historical past is applicable for carrying out analogies, for understanding negative consequences of person's impact on the nature. Upon the increase of environmental problems "the complexity barrier" in their solution will become more and more difficult to overcome; new levels of scientific efforts to reveal them, complex research and solutions will be required. It enhances the significance of ecological history in the theoretical solution of a global environmental problem.

The analysis of Russian and foreign researches on the problems of person's and environment interaction the typical feature of which is its interdisciplinary character allowed to determine that the historical and ecological perspective has been developed mainly abroad since the 1960s, and in our country—only since the 1980-1990s (Platonov, 1989; Vasilyeva, 1985; Bondarev, 1999). Special researches of European, American and Asian ecological historians allowed to designate prospective guidelines for the Russian scientists concerning such studies of contradictions in the system "person-nature" as: sources and evolution of industrial pollution, environmental problems of urbanized territories, dynamics of natural resources exhaustion, water resources management history, etc. (LeCain, 2000; Cumbler, 2000; Meikle, 1997; Travis, 1997; McCarthy, 2001).

Ecological issues in works of Russian researchers were considered at later stages though the historical component was quite often present in works of historians, philosophers, ecologists, geographers and representatives of other sciences; it served as a basis for special studying of historical aspects of nature protection problems. At the same time the analyzed domestic historiography of the issue showed both certain achievements and essential gaps in the historical research of environmental problems. Since the beginning of the 1980s historians did not manage to create conceptual and analytical works devoted to environmental problems the the economic development of the country. Only in recent years there start appearing serious historical researches considering various aspects of ecologic-economic contradictions in relation to certain regions of Russia (Kuzmin, Orudzhiyeva, \& Alferova, 1997; Tolstikov, 1999; Bakunin \& Lebedev, 1991; Gavrilov, 1992).

\section{Results}

The priority direction of ecological history is the historical research of ecologic-economic contradictions which have increased dramatically since the first stages of human evolution. The most significant reason of the crisis between the society and nature has become the consumer attitude to nature and natural resources that has been developed throughout centuries and that has resulted in the violation of balance in ecosystems. Natural cataclysms directly or indirectly accompanying humankind since the most ancient times and bearing destructive potential in them assumed the menacing scale which affected, first of all, the state of world economy in the end of the XXth century.

In this regard environmental problems are considered in combination with economic ones as, first, ecological contradictions are the result of economic ones, and secondly, the aggravation of environmental problems resulted in negative phenomena in economy turning into the source of social tension in the society.

In the second half of the XXth century the world economy, and especially industrial production, entered the period characterized by deep transformation of capitalism caused by dynamic changes in the development of productive forces in connection with the third scientific and technical revolution, growth of production internationalization, deepening of international job specialization, and differentiation. This process was accompanied by the transition to resource- and labor saving, environmentally friendly, knowledge-intensive productions and technologies since the 1970s on the basis of which there occurred a structural adjustment of economically developed countries that caused steadiness and even some decrease in industrial pollution in industrially developed countries and the moving of ecologically harmful productions to developing countries.

It is possible to state that the Russian Federation where morally and physically outdated technologies have polluted the environment for decades is regarded as the territory of considerable ecological degradation. Due to 
these reasons the ecological situation in modern Russia continues to remain rather difficult, and in some cities and regions even critical. Heavy industry, oil production, energy engineering, chemistry and petrochemistry impacted and still impact the quality state of natural resources. Their development was under the influence of industry interests without due consideration of ecological factors (air resources condition, water and land resources, flora and fauna, the health of population and the level of incidence).

The experience of industrial leaders' development in Middle Volga area-the Republic of Tatarstan and the Samara region - showed that it is difficult to find examples of regions with similar high rates of industrial growth and such close attention of the party and government institutions in the Russian history of the second half of the XXth century. The economy of the country experienced a lot of troubles at that time and therefore had to accelerate the development of new advanced industries. The advancing growth of oil production, petrochemical, machine-building complex established by the decision guidance of regular party congresses was determined due to the same reasons.

The creation of developed industry in Middle Volga had both positive had also negative consequences, first of all, they are of social-economic and ecological character. The construction of some enterprises, the products of which were of great importance for the country, had potential inevitability of economic, social and ecological equilibrium rational balance violation. Excessive priority of time factor in the achievement of the fastest terms of production capacities commissioning in the context of which there was traced the aspiration to prove the benefits of the socialist system and the system of planned economy, generated a considerable lack of attention to the solution of social and nature protection tasks that resulted in considerable decline of the population life quality.

The historical and ecological analysis of industrial leaders' development in Middle Volga area in the second half of the XXth century allowed to single out the reasons of the environment critical condition which developed in the region at a turn of the XX-XXIth centuries:

- The economy aimed at the maximum involvement of natural resources into anthropogenic activities and which did not take into account the direct needs of the population ;

- The technocratic approach to the solution of environmental problems directed not towards radical social and economic transformations, but quantitative, superficial changes which, in particular, only increase the property impersonality of natural resources;

- Contradictions evolving from the discrepancy of imperfect, uneconomical technologies and equipment to the requirements of rational environmental management that may therefore lead to national ecological crisis;

- Irresponsibility and absence of control of the relevant ministries, departments, regional and municipal bodies the activities of which are quite often aimed not at the environmental benefit, but its damage;

- Lack of sufficient economic interest and responsibility of enterprises and organizations in the implementation of nature protection activity which is not integrated with their core business now;

- Unilateral consumer approach in favour of momentary economic interests the consequence of which is the absence of prospective strategic beginning in nature protection activities;

- The low level of ecological culture, education and consciousness of the population as well as administrative, scientific and technical bodies of relevant departments and organizations;

- Closed and undemocratic character of nature protection and controlling departments and organizations work (Kalimullin, 2006).

Considering the nature protection policy of state and regional authorities in the sphere of industrial production, it is necessary to pay attention to the fact that its insufficient efficiency was explained not only by the priority of production indicators in combination with obvious technical miscalculations, but also by unduly realized opportunities of the economic system of the Soviet state. The new system of nature protection activities created since the late 1980s on the basis of legal and economic regulation gained efficient forms only by the end of the 1990s that did not allow to change cardinally the tendency of ecological degradation in the country.

The necessity to stabilize the ecological situation in the country allows to formulate the prioritized guidelines of technological policy enhancement in the field of environmental protection at the present stage. First, it is consecutive transition to international ecologically safe standards of engineering procedures and production; secondly, the development and stimulation of low-waste, resource- and energy-saving technologies, processes; thirdly, activation of research and development works, investment projects of ecological orientation.

Statistical and actual data show that at present due to the influence of productive activity in Middle Volga region there are hundreds of chemical polluting substances in the atmosphere air that interacting with each other either 
strengthen or neutralize their impact. In the majority of reservoirs due to the discharge of untreated and partially treated wastewater of industrial and household origin, there occurs the change of structure and composition of ichthyofauna, decrease of fish inventories.

Summing up recommendations formulated in various legislative and executive documents, nature protection and other programs on the stabilization of the ecological situation in industrially developed regions of Middle Volga it is necessary, in our opinion, to single out the following prioritized tasks:

1) Removal of large urboekosystems (Samara, Tolyatti, Syzran, Kazan, Naberezhnye Chelny, Nizhnekamsk, Almetyevsk, etc.) and some other industrial centers from a difficult ecological situation.

2) Overcoming of territories radioactive pollution consequences (as a result of Chernobyl accident-in the right-bank and zakamsky regions of Tatarstan; as a result of technogenic origin - in the cities of Kazan, Chistopol, Mendeleevsk, Zhigulyovsk; in the area of oil-producing enterprises, cross-border pollution from Balakovo NPP, NIIAR in the city of Dmitrovgrade, etc.).

3) Development and enhancement of the system of especially protected natural territories, natural complexes of recreational and resort use.

4) The solution of environmental problems in oil production areas.

5) Participation in the implementation of federal target programs "Renaissance of the Volga", "Waste products", "Revival, Construction, Reconstruction, and Restoration of the Historical Small-size and Average-size Cities of Russia”, etc.

6) Providing population with high-quality fresh water.

7) The limitation of discharges (dumpings) of polluting substances and the prevention of atmospheric air and water objects pollution.

8) Prevention and reduction of dangerous impact of natural disasters, technogenic accidents and catastrophes.

9) The organization of the efficient system of the state ecological regulation and control of the environment condition according to management levels on the basis of an ecosystem approach.

10) Ecological education and enlightenment, upbringing, training, information servicing.

11) Collaboration with public ecological organizations.

It is natural that the considerable part of these nature protection tasks will be solved only on the basis of comprehensive ecologic-economic analysis of current trends of productive forces placement, concentration of production and forming of large industrial units. In this connection, it is necessary to admit that the dilemma "economic development and deterioration of the environment" is the reality of both today and tomorrow that requires optimum parameters of their balanced ratio.

\section{Conclusion}

The complex combination of natural-anthropogenic impacts, among which industrial impact is the most significant and problematic, serves, in our opinion, as the basis for forecasts of further ecological situation aggravation. In this regard the following prospective guidelines of environment condition optimization in Middle Volga area seem to be the most important:

- The solution of land rational use issues including protection against wind and water erosion, flooding, bogging and salination;

- Decrease in chemical loading of soil;

- Efficiency increase of water resources utilization and protection, including the improvement of small rivers condition, water storage basins, control of underground waters condition

- Enhancement of actions aimed at the protection of atmospheric air due to treatment facilities and installations;

- Creation of waste treatment infrastructure;

- Extension of reserves, national parks and wildlife areas network;

- Intensification of works aimed at the protection, reproduction and rational use of a plant and animal life;

- Improvement of population health and life quality.

\section{Recommendations}

Thus, the conclusions of historical-ecological researches shall promote effective use of economic, legal, 
technological, moral and organizational methods aimed to impact the forming economic system, its maximum ecologization to balance the sustainability of diverse processes: economic development of the country and creation of the environment favorable for person's life and health.

\section{Acknowledgments}

The work is performed according to the Russian Government Program of Competitive Growth of Kazan Federal University

\section{References}

Bakunin, A. V., \& Lebedev V. E. (1991). Regional scientific and technical policy: History issues. Sverdlovsk.

Bondarev, L. G. (1999). History of environmental management (Historical ecology): Studies guide for students of geographical faculty of higher education institutions. Moscow.

Bragina, S. V., Ignatovich, I. V., \& Saryan, E. D. (1999). Relationship of society and nature: Short historical sketch. Moscow.

Cumbler, J. T. (2000). Conflict, Accommodation, and Compromise: Connecticut's Attempt to Control Industrial Wastes in the Progressive Era. Environmental History, 5(3), 314-335. http://dx.doi.org/10.2307/3985479

Gavrilov, D. V. (1992). Ecological problems of Ural mining region at the end of the XIXth-The beginning of the XXth centuries. In Ural industry in the period of capitalism: Social, economic and ecological problems [collection of research papers] (pp. 89-121). Yekaterinburg.

Kalimullin, A. M. (2006). Issues of ecological history. History Issues, 10, 160-165.

Kalimullin, A. M. (2015). Ecological Problems of Middle Volga in the Second Half of the XXth Century: Historical and Ecological Analysis of Leading Industrial Regions Development. Review of European Studies, 7(1), 86-93.

Kalimullin, A. M., \& Vinogradov, A. V. (2015). Ecological and Sanitary Problems of Kazan Province Industrial Development in the XIXth and Early XXth Centuries. Review of European Studies, 7(1), 188-194.

Kuzmin, A. I., Orudzhiyeva, A. G., \& Alferova, E.Y. (1997). Social and demographic consequences of radiation disasters in the Urals. In Historical experience of interaction of a human and environment in the Urals (pp. 130-145). Yekaterinburg.

LeCain, T. (2000). The Limits of 'Eco-Efficiency': Arsenic Pollution and the Cottrell Electrical Precipitator in the U.S. Copper Smelting Industry. Environmental History, 5(3), 336-351. http://dx.doi.org/10.2307/3985480

Matveyeva, S. A. (1996). Culture of environmental management in historical dynamics (pp. 64-66). International conference "Ecological experience of humankind: The past in the present and the future": Scientific abstracts.

McCarthy, T. (2001). The Coming Wonder? Foresight and Early Concerns about the Automobile. Environmental History, 6(1), 46-74. http://dx.doi.org/10.2307/3985231

Meikle, J. L. (1997). Material Doubts: The Consequences of Plastic. Environmental History, 2(3), 278-300. http://dx.doi.org/10.2307/3985351

Palekhova, P. V. (1991). Russian society: History and ecology. Moscow.

Pidzhakov, A. Y. (1996). Ecological policy of the USSR, the mid of the 60s-The beginning of the 90s (Thesis PhD., Saint Petersburg).

Platonov, G. V. (1989). Problem of history periodization of society and nature relationship. In Problems of interaction of a human and biosphere (pp. 202-208).

Pushkarenko, A. A. (2000). Nature protection activity in the area of Donskoy's army in the second half of XIXth-The beginning of the XXth centuries (Thesis PhD., Rostov-on-Don).

Sokolov, V. V. (1994). Sketches of Russia's ecological policy history. Saint Petersburg.

Sokolov, V. V. (1995). The history of ecological policy in the Russian Federation (Thesis PhD., Saint Petersburg).

Tolstikov, V. S. (1999). Social and ecological consequences of the nuclear industry development in the Urals: Historical aspect (Thesis PhD., Chelyabinsk). 
Travis, A. S. (1997). Poisoned Groundwater and Contaminated Soil: The Tribulations and Trial of the First Major Manufacturer of Aniline Dyes in Basel. Environmental History, 2(3), 343-365. http://dx.doi.org/10.2307/3985354

Tupikov, A. V. (1993). Ecological policy of the Soviet state in the 70-80s (On the materials of government bodies, party and public organizations of Volga region) (Thesis PhD., Saratov).

Vasilyeva, V. N. (1985). Historical development of environmental management and principles of its rationalization. (Thesis $\mathrm{PhD}$., Moscow).

\section{Copyrights}

Copyright for this article is retained by the author(s), with first publication rights granted to the journal. This is an open-access article distributed under the terms and conditions of the Creative Commons Attribution license (http://creativecommons.org/licenses/by/3.0/). 